\title{
KREATIVITAS DWIYASMONO DALAM KARYA TARI HARJUNA KERATARUPA
}

\author{
Fitri Monika Sari \\ Institut Seni Indonesia (ISI) Surakarta \\ Jalan Ki Hadjar Dewantara No.19, Kentingan, Jebres, Surakarta 57126 \\ Nanik Sri Prihatini \\ Institut Seni Indonesia (ISI) Surakarta
}

\begin{abstract}
This research focuses on Dwiyasmono's creativity in creating Harjuna-Keratarupo Dance. Harjuna-Keratarupo Dance is a phetilan dance two adult males. Issues raised in the research is about the form of Harjuna-Keratarupo Dance. And about Dwiyasmono's creativity in the Creations of Harjuna-Keratarupo Dance. This research is a Qualitative research using descriptive methods of analysis and the technical collection of observations, interviews, bibliography studies and Documents. To analyse the shape of the dish using form concepts expressed by Suzane K. Langer and its elements the constituent was outlined using Soedarsono's theory. To Explain Dwiyasmono's creativity analyzed using theory Rhodes that creativity there are four elements, namely person, press, process, product. The results of the research known as Harjuna-Keratarupo Dance in the form of a divided into three parts, namely the Maju Beksan, Beksan and Mundur Beksan. This dance has the merging of two styles of dance motion. Dwiyasmono's creativity in the cupping section of the Surakarta movement is combined with the movement of Yogyakarta style. The dance music in the dance is colored with a leather puppet pack. The development of the garage is influenced by external factors and internal factors, especially for its withdrawal.
\end{abstract}

Keywords: Harjuna Keratarupo, form, Dwiyasmono, creativity.

\section{PENDAHULUAN}

Tari Harjuna - Keratarupo merupakan salah satu bentuk kreativitas yang bersumber pada tari tradisi gaya Surakarta. Menurut SD. Humardani tari tradisi adalah tari yang berpedoman ketat pada tata dan aturan yang telah ditentukan oleh para empu tari terdahulu, aturan tari yang dimaksud adalah teknik dan wujud gaya suatu ciri khas kedaerahan (Prihatini, dkk, 2007: 41). Tari tradisi gaya Surakarta merupakan tari tradisi yang tumbuh dan berkembang di keraton Surakarta. Tari tradisi tidak hanya ada dan berkembang di keraton Surakarta, namun di keraton Yogyakarta juga terdapat tari tradisi gaya Yogyakarta. Adanya persamaan tradisi keraton Surakarta dan Yogyakarta membuat seniman tertarik untuk meciptakan karya tari dengan mempadukan dua gaya tari tersebut. Salah satu contohnya adalah Dwiyasmono yang meciptakan Tari Harjuna-Keratarupo. Kreativitas dalam 
memadukan gaya tersebut menarik untuk diangkat dalam penelitian.

Dwiyasmono merupakan salah seorang koreografer yang terbukti karya karya yang diciptakan tetap konsisten pada bentuk - bentuk tari tradisi alus gaya Surakarta yang memang merupakan basicnya. Terjun di dunia kesenian masih beliau tekuni sampai saat ini. Dwiyasmono menciptakan Tari Harjuna - Keratarupo pada tahun 1995. Karya Tari Harjuna Keratarupo diciptakan sebagai perwujudan hasil karya dosen di Institut Seni Indonesia Surakarta. Karya Tari Harjuna Keratarupo merupakan suatu bentuk karya tari gaya Surakarta bertemakan perangan yang berkarakter putra alus dengan genre tari phetilan. Phetilan merupakan salah satu genre tari Jawa yang memetik dari sebuah cerita (Prihatini, dkk, 2007: 119).

Tari Harjuna-Keratarupo merupakan salah satu genre tari pethilan karena tari ini diambil dari cerita Mahabharata dalam salah satu episode Arjuna Wiwaha. Tari HarjunaKeratarupo ditarikan dua orang penari putra dewasa, yaitu dengan satu penari sebagai Arjuna yang berkarakter putra luruh dan satu penari sebagai Keratarupo yang berkarakter putra lanyap. Dalam karya Tari Harjuna - Keratarupo terdapat dua tokoh dalam pewayangan yaitu Begawan Ciptaning atau Arjuna dan Raden Keratarupo atau yang merupakan jelmaan dari Bathara Guru.

Karya tari ini pertama kali dipentaskan pada tanggal 15 April 1995 di pendhapa Ageng ISI Surakarta dalam acara pementasan karya tari dosen ISI Surakarta, dengan penari Dwiyasmono yang berperan sebagai Harjuna dan Matheus Wasi Bantolo sebagai Keratarupo (Dwiyasmono, wawancara 19 September 2018). Dwiyasmono dan Wasi Bantolo merupakan penari yang memiliki ketubuhan sangat baik khususnya untuk tari tradisi alus gaya Surakarta (Wahyu Santoso Prabowo, wawancara 27 September 2018).

Tari ini selanjutnya pernah ditarikan oleh Irwan Dhamasto dan Dhestian Wahyu Setyaji. Pada tahun 2018 Tari Harjuna Keratarupo dijadikan salah satu materi Ujian Pembawaan tari putra alus Institut Seni Indonesia Surakarta yang dipentaskan di Desa Windusari, Magelang dan ditarikan oleh Ahmad Saroji dan Damasus Chrismas Verlananda Waskito. Hingga sekarang tarian ini dijadikan sebagai materi wajib untuk perkuliahan mata kuliah tari Surakarta alus semester V di Institut Seni Indonesia Surakarta.

Keunikan karya tari ini adalah dalam bentuk ragam gerak yang menggabungkan ragam gerak tari gaya Yogyakarta dan ragam gerak tari gaya Surakarta ke dalam struktur garap sajiannya. Tarian ini memiliki tingkat kesulitan tersendiri dalam menarikannya. Sebagai penari selain harus hafal dan memiliki teknik menari yang tepat namun juga harus mampu berekpresi sesuai kesan yang akan disampaikan. Selain itu, dalam tarian ini memiliki struktur garap iringan (gending) yang lebih menekankan pada penggambaran suasana agar memacu rasa yang terbangun oleh para penari yang membawakannya. Oleh karena itu dibutuhkan penari - penari yang memang memiliki kemampuan menari dan menyampaikan sajian yang baik. Melihat dari beberapa fenomena yang muncul maka peneliti tertarik menulis bentuk sajian dan proses kreatif penciptaan Tari Harjuna Keratarupo, untuk itu judul penelitian ini 
yaitu "Kreativitas Dwiyasmono dalam Karya Tari Harjuno Keratarupo".

PROSES PENCIPTAAN TARI HARJUNA KERATARUPO KARYA DWIYASMONO

Proses penciptaan Tari Harjuna Keratarupo oleh Dwiyasmono merupakan kerja kreatif dalam rangka menghasilkan karya barunya. Dalam proses ini diperlukan tindakan kreatif. Seperti yang disebutkan dalam Kamus Besar Bahasa Indonesia dan Utami Munandar. Kreativitas merupakan sebuah kemampuan untuk menciptakan atau daya cipta (KBBI). Utami Munandar juga menyatakan kreativitas adalah umum untuk menciptakan sesuatu yang baru, atau memberi gagasan - gagasan baru yang dapat diterapkan dalam pemecahan masalah, juga sebagai kemampuan untuk melihat hubungan hubungan baru antara unsur - unsur yang sudah ada sebelumnya. Hal tersebut berarti sebuah kemampuan untuk membuat kombinasi baru, berdasarkan data, informasi, atau unsur - unsur yang ada (1999: 28, 33).

Kreativitas yang dimiliki setiap orang tentu berbeda - beda sesuai dengan pengalaman yang didapat setiap individu. Pengalaman - pengalaman yang didapatkan koreografer akan dijadikan pengeksplorasi ide - ide yang diwujudkan dalam gerakan. Dwiyasmono dan kemampuan tari yang terdapat pada dirinya merupakan satu kesatuan yang tidak dapat dipisahkan dari kehidupannya. Berawal dari pengalaman sebagai seorang penari dan sekarang sebagai seorang koreografer. Dwiyasmono dalam karya Tari Harjuna - Keratarupo terlihat ciri khasnya terutama pada tari tradisi gaya Surakarta. Karya tarinya merupakan sebuah pengembangan diri dari pengalaman sebagai penari kemudian dituangkan dalam karya-karyanya dengan ekspresi terhadap ide dan gagasannya. Sejalan dengan hal tersebut Munandar berpendapat bahwa:

Gaya hidup kreatif yang terdapat pada seseorang diartikan sebagai pengembangan talenta yang dimiliki, tetap terus belajar menggunakan kemampuan yang dimiliki secara optimal, melakukan aktivitas aktivitas baru dan harus tetap mengembangkan kepekaan terhadap masalah lingkungan di sekitarnya (2002:25).

Kreativitas dan pengalaman tari pada diri Dwiyasmono diwujudkan dalam bentuk yang nyata yaitu berupa karya Tari Harjuna - Keratarupo. Tari Harjuna - Keratarupo sebagai karya tari yang dapat dinikmati dengan panca indera, yang merupakan satu ekspresi perasaan yang muncul dalam diri koreografer yang dirubah oleh imajinasi dan diberi bentuk melalui gerak. Pendapat Soedarsono terkait dengan kreativitas menyatakan bahwa berbagai seni muncul karena adanya kemauan yang ada pada diri manusia untuk mempelajari pandangan dari pengalaman hidupnya serta didasari atas kemauan dalam memberikan bentuk yang nyata (1978: 38). Hal ini sesuai dengan Dwiyasmono dalam penciptaan karya seni yang berupa Tari Harjuna - Keratarupo yang tidak lepas dari kemauan dan pengalaman Dwiyasmono sendiri untuk menciptakan Tari Harjuna - Keratarupo.

Kreativitas selain dipengaruhi oleh pengalaman koreografer, terdapat faktor faktor yang mempengaruhinya, yaitu faktor internal dan faktor eksternal. Faktor internal terdiri dari ciri khas pribadi dan 
pengalaman pribadi. Pengalaman pengalaman yang merangsang dan memberi semangat proses penghayatan, perasaan, imajinasi, dan pengekspresian. Faktor eksternal merupakan kondisi- kondisi yang perlu untuk membangun kreativitas. Dalam hal ini pertumbuhan kreatif dapat berkembang secara baik pada lingkungan yang memungkinkan seseorang untuk menemukan dan mengeksplorasi imajinasinya. Hal tersebut sesuai pendapat Soedarsono bahwa:

Bagi siapa saja yang mau mengutamakan kreativitas maka harus tahu bagaimana menciptakana kondisi-kondisi eksternal yang akan memelihara kondisi internal yang perlu untuk hadirnya kreativitas. Karena memang kedua kondisi tersebut saling berkaitan satu sama lain. Selain harus menciptakan kondisi eksternal yang baik, terdapat pula kemana psikologis dan kebebasan. Keamanan psikologis dan kebebasan psikologis sangat dibutuhkan oleh koreografer, yaitu hal yang menyangkut mengenai suasana bebas, memperoleh pengertian, dan tentunya memberi dorongan atau semangat, karena karya kreatif dapat dinilai dari hal yang tumbuh dari individu dan bukan untuk dibandingkan dengan yang lain (1987: 39).

Kreativitas yang muncul dari masing - masing koreografer memiliki ciri khas berbeda dengan koreografer lain sesuai dengan lingkungan pendukung dan pengalamannya. Pengalaman Dwiyasmono selama menjadi penari mempengaruhi terhadap karya tarinya. Hasil ini terlihat pada teknik gerak yang mapan pada setiap motif gerak karya tarinya. Selain itu bakat yang dimiliki oleh Dwiyasmono juga mempengaruhi terhadap kreativitas pada karya tarinya. Hal ini sesuai dengan pendapat Soedarsono yang menyatakan.

Menjadi seorang penari dan koreografer hebat diperlukan bakat yang besar yang didapatkan sejak ia dilahirkan. Selain bakat, seorang koreografer dan penari harus memiliki perwujudan fisik yang baik, karena memang bahan buku utama dari tari adalah gerak tubuh manusia (1978: 8).

Dwiyasmono merupakan seorang penari yang cukup memiliki fisik yang kuat karena dia merupakan seorang yang gemar berolahraga, selain itu dalam pendidikannya di STSI Surakarta atau ISI Surakarta olah tubuh sebagai penari selalu diajarkan dalam perguruan tinggi tersebut untuk mendukung stamina kepenariannya (Dwiyasmono, wawancara 19 September 2018).

Kreativitas Dwiyasmono ciri khasnya ditentukan dengan dimana dia menuntut ilmu pendidikan tentang seni, STSI Surakarta yang lingkup besarnya mengajarkan tari tradisi gaya Surakarta. Oleh karena itu kreativitas seorang koreografer tidak terlepas dari bakat, pengalaman, dan budaya yang melingkupinya. Pembahasan mengenai kreativitas Dwiyasmono dalam menciptakan Tari Harjuna - Keratarupo atau dalam berproses menggunakan konsep Utami Munandar, yang menyatakan kreativitas terdiri dari pribadi (person), pendorong (press), proses (process), dan produk (product).

Berdasarkan konsep tersebut menjelaskan pula adanya hubungan antara 
keempat unsur tersebut yaitu pribadi (person), pendorong (press), proses (process), dan produk (product). Munandar menjelaskan bahwa apabila kita memfokuskan analisis terhadap proses kreatif maka kita dapat mengetahui bagaimana jenis pribadi yang berhasil dalam proses kreatif tersebut, pendorong berupa lingkungan yang mempengaruhi dalam proses kreatifnya, dan bagaimana lingkungan yang mempermudah dalam proses kreatifnya, dan bagaimana produk yang dihasilkan dari proses kreatif tersebut (2002: 28).

\section{PRIBADI (PERSON)}

Dwiyasmono merupakan seorang Dosen Institut Seni Indonesia Surakarta yang lahir di Trenggalek, pada tanggal 25 Juli 1962. Dwiyasmono menikah dengan Siti Dwi Lestari dan memiliki 2 anak perempuan dan laki - laki. Dwiyasmono terlahir dari pasangan yang memiliki bakat seni, bapaknya bernama Moedjianto dan ibunya bernama Moesrini. Moedjianto merupakan salah seorang seniman didaerahnya yang menekuni kesenian wayang orang.

Bakat yang dimiliki Dwiyasmono dalam dunia seni sudah dimilikinya sejak lahir atau karena faktor genetis (keturunan), selain itu bakatnya berkembang dari ketekunan mempelajari seni tari. Dwiyasmono mulai mengenal seni tari sejak ia masih kecil dengan melihat dan ikut menjadi penari jaranan yang merupakan kesenian di daerahnya yaitu di Trenggalek. Sebelum mengenal pendidikan dalam bidang seni Dwiyasmono mengawali pendidikan di SD N 1 Trenggalek lulus pada tahun 1974. Perjalanan dalam menempuh sekolah pendidikan dasar, pengalaman kesenian yang dialami Dwiyasmono yaitu pernah ikut serta dalam pertunjukan wayang orang pada sekelompok seniman wayang orang Tibrata. Dwiyasmono berperan sebagai Cantrik, pagelaran yang ditampilkan di Trenggalek sebagai sarana tontonan dan hiburan bagi masyarakat dalam menikmati malam minggu. Semenjak itu Dwiyasmono menjadi dikenal warga dan gurunya, penampilan jaranan merupakan salah satu pentas Dwiyasmono dalam acara sekolah perpisahan kelas 6 (Dwiyasmono, wawancara 15 November 2018).

Dwiyasmono melanjutkan pendidikan di SMP N 1 Trenggalek lulus pada tahun 1977, pada jenjang SMA/MA beliau sekolah di SPG Trenggalek yaitu Sekolah Pendidikan Guru lulus pada tahun 1981. Menentukan pendidikan perguruan tinggi yang akan diambil merupakan salah satu kebimbangan yang dialami oleh Dwiyasmono. IKIP Surabaya merupakan sasaran awal untuk melanjutkan sekolah perguruan tinggi, meskipun sudah diterima diperguruan tinggi tersebut bukan berarti tidak dapat mengubah minat Dwiyasmono. Istini adalah teman Dwiyasmono yang berhasil mengubah minat Dwiyasmono dan mengajak untuk menempuh pendidikan di ASKI Surakarta. Selain Istini yang merupakan teman Dwiyasmono di desa, Agus Tasman yang dulu dosen di ASKI Surakarta, juga merupakan orang yang mebujuk Dwiyasmono untuk bersekolah di ASKI Surakarta mengikuti pendaftaran gelombang kedua. Berangkat dari minat menempuh pendidikan di bidang seni yang dimilikinya, Dwiyasmono mulai menekuni bidang seni (Dwiyasmono, wawancara, 19 September 2018).

Pembelajaran yang ditempuh dan ditekuni selama 4 tahun di ASKI Surakarta 
menambah wawasan dan pengalamannya dalam bidang seni tari. Diluar menuntut ilmu tentang seni tari di ASKI Dwiyasmono juga mencari pengalaman - pengalaman untuk menambah wawasannya dengan khursus tari kepada S.Maridi. Tari Eko Prawiro, Tari Watang, Tari Sanjoyo Kusumawicitra dan Tari Harjuna Sasra Sumantri merupakan tari yang diajarkan oleh S.Maridi pada sejak itu. Mangkunegaran merupakan salah satu sanggar yang diminati Dwiyasmono dalam menggali ilmu kesenian tari. Ketekunan dan kegigihan Dwiyasmono membuahkan hasil dengan diangkatnya Dwiyasmono menjadi penari di Mangkunegaran. Kualitas Dwiyasmono mulai terlihat semester 3S1, melalui Nanik Sri Prihatini ia mendapatkan penawaran dari SD. Gendon Humardani menjadi asisten dosen di ASKI, Dwiyasmono memilih untuk tetap fokus terdahulu dalam studi pendidikannya (Dwiyasmono, wawancara 15 November 2018).

Dwiyasmono lulus pada tahun 1986 dengan perwujudan dari ilmu yang ia tekuni berhasil mewujudkan sebuah karya pada Tugas Akhir Drama Tari Karno Tanding. Dimana Dwiyasmono dalam karyanya berkolaborasi dengan F.R Nanik yang berperan sebagai Dewi Kunti dan Dwiyasmono berperan sebagai Janoko. Setelah lulus dari ASKI Surakarta Dwiyasmono berprofesi menjadi seorang pekerja seni atau seorang penari. Tahun 1988 Dwiyasmono mendapatkan kesempatan menarikan Lambangsing bersama Hadawiyah Endah Utami pada acara pernikahan putri S. Maridi pada tahun 1988. Melihat kepenarian Dwiyasmono yang cukup bagus Agus Tasman menawarkan agar Dwiyasmono dan Hadawiyah Endah
Utami untuk menjadi dosen ASKI Surakarta. Dwiyasmono menjadi dosen ASKI Surakarta pada tahun 1988 dan diangkat sebagai PNS pada tahun 1989. Perjalanan menjadi seorang dosen dituntut banyak hal selain memiliki banyak pengetahuan ilmu tentang seni khususnya seni tari sesuai dengan bidangnya, Dwiyasmono dituntut untuk menciptakan sebuah karya dosen yaitu dengan menciptakan karya Tari Harjuna Keratarupo. Tari Harjuna-Keratarupo merupakan wujud dari ilmu dan pengalaman yang beliau tekuni dari awal hingga sampai menjadi seorang dosen (Dwiyasmono, wawancara 15 November 2018).

\section{PENDORONG (PRESS)}

Kreativitas agar bisa terwujud diperlukan dorongan dari individu maupun dorongan dari lingkungan. Pendorong atau motivasi dalam melakukan kreativitas terdiri dari dua faktor yaitu internal dan eksternal, dalam dunia tari disebut sebagai faktor intrinsik dan faktor ekstrinsik. Dimana kedua faktor tersebut selalu berkaitan dan mempengaruhi satu sama lain terhadap pribadi seseorang.

\section{Faktor Internal}

Faktor pendorong internal yaitu bahwa setiap individu memiliki kecenderungan atau dorongan mewujudkan potensinya, mewujudkan dirinya, dorongan berkembang menjadi matang, dorongan mengungkapkan dan mengaktifkan semua kapasistasnya (Sulastuti, 2017:250).

Pada karya Tari Harjuna Keratarupo faktor pendorong internal yang sangat kuat mempengaruhi terlihat pada modal atau kekuatan Dwiyasmono sebagai 
penari dan dosen tari, serta kebiasaan Dwiyasmono dalam menarikan tari - tari klasik gaya Surakarta. Kekuatan - kekuatan Dwiyasmono merupakan faktor pendorong internal diartikan pula keinginan yang berasal dari dalam diri Dwiyasmono tanpa adanya paksaan dari orang lain. Hal ini sesuai dengan keinginan Dwiyasmono dalam menciptakan Tari Harjuna - Keratarupo bernuansa baru berdasarkan pada pengalaman - pengalaman yang ia dapatkan dan ia miliki baik sebagai penari maupun seorang koreografer. Berprofesi sebagai dosen seni tari ISI Surakarta membuat Dwiyasmono memiliki adanya pertanggung jawaban moral guna mengembangkan, berbagi, mewujudkan dan menambah referensi tarian bagi ISI Surakarta. Terkait dengan perlunya pengkayaan materi bahan ajar Tari Putra Alus Gaya Surakarta. Keinginanya dapat terwujud berkat kerja kerasnya dan kekutaannya.

Faktor internal yang merupakan kekuatan dan modal utama Dwiyasmono dalam menciptakan Tari Harjuna Keratarupo sehingga dapat dilihat kreativitasnya Dwiyasmono pada karta Tari Harjuna - Keratarupo yang memiliki corak dan kualitas kemapanan teknik, dan keragaman gerak. Kreativitas dan kemampuan menginterpretasi yang dimiliki Dwiyasmono juga merupakan faktor pendorong yang dimilikinya. Hal tersebut akan memungkinkan munculnya gambaran intrepretasi dari cerita atau peristiwa, interpretasi suasana atau rasa, serta interpretasi gerak yang kemudian mewadahi suatu isi yang dipilih dan dibutuhkan. Seluruh kemampuan interpretasi tidak akan terlepas dari kepekaan serta daya imajinasi yang masing - masing koreografer miliki. Keinginan dan kemampuan yang dimiliki Dwiyasmono mendorong dirinya untuk tetap menghasilkan karya tari. Karya tarinya dapat disusun berdasarkan kenangan atau memori yang terdapat dalam dirinya, atau dapat pula memori lain dari luar dirinya.

\section{Faktor Eksternal}

Faktor eksternal dalam hal ini dimaksudkan sebagai dorongan berkarya yang muncul dari luar diri seseorang. Selain faktor internal sebagai pendorong penciptaan karya Tari Harjuna - Keratarupo, faktor eksternal juga mendorong Dwiyasmono menciptakan karya tari tersebut. Kemampuan eksternal tersebut didukung oleh lingkungan yang membesarkannya dari sejak ia lahir seperti halnya lingkungan keluarga, lingkungan pendidikan dan lingkungan sosial. Hal tersebut dibuktikan oleh Dwiyasmono yang saat ini menjadi seorang seniman khususnya di bidang seni tari yaitu sebagai penari dan koreografer. Lingkungan keluarga yang selalu mendukung karya - karyanya dan menyemangati Dwiyasmono, Dwiyasmono terlahir dari keluarga seniman yaitu ayahnya sebagai pelaku seni wayang orang di daerahnya Trenggalek. Ada pula lingkungan pendidikan dan lingkungan sosial yang mendorongnya dalam melakukan kreativitasnya. Dwiyasmono dikelilingi oleh lingkungan pendidikan dan lingkungan sosial yang kondusif.

$$
\text { Lingkungan Pendidikan yang }
$$

Dwiyasmono tempuh khusus mempelajari seni, minat menempuh di pendidikan kesenian khususnya seni tari muncul dari ajakan sahabatnya yaitu Istini, selain 
lingkungan pendidikan lingkungan sosial yang mempengaruhi kreativitas Dwiyasmono yaitu lingkungan sosial seperti halnya Dwiyasmono mengikuti sanggar di Mangkunegaraan. Lingkungan kesenian yang mendukungnya mempermudah ia dalam melakukan kegiatan kesenian dan beraktivitas. Faktor eksternal yang mempengaruhi penciptaan karya Tari Harjuna-Keratarupo yaitu melihat tari yang mengambil dari kisah Arjuna Wiwaha. Perlu diketahui Dwiyasmono bukan orang pertama yang menciptakan karya tari berangkat dari kisah dalam cerita Arjuna Wiwaha. Karya-karya tari serupa sudah terlebih dahulu diciptakan baik di dalam lingkungan Istana Mangkunegaran maupun oleh tangan-tangan penari Jawa kreatif seperti: S. Ngaliman dan S. Maridi. Salah satu karya yang sudah ada yaitu berjudul Harjuna Sasrasumantri yang berada di Mangkunegaran. Hal tersebut menjadikan keinginan yang lebih kuat dari Dwiyasmono ingin mengembangkan cerita dan jenis tarian yang mengangkat dari cerita Harjuna.

Kreativitas yang dimiliki Dwiyasmono dalam hal ini tidak hanya bergantung pada keterampilan dalam bidang tari saja tetapi juga adanya motivasi dari dalam diri koreografer untuk melakukan kreativitas. Faktor Internal koreografer mendapat dorongan yang besar dari faktor eksternal. Kedua faktor tersebut tidak dapat dipisahkan satu dengan yang lain karena kedua faktor tersebut saling mempengaruhi dalam menyusun sebuah karya tari yang dihasilkan. Faktor pendorong atau motivasi pada diri Dwiyasmono sangat berpengaruh dalam menciptakan dan menyusun karya tarinya.

\section{PROSES (PROCESS)}

Proses merupakan hal yang penting dalam mewujudkan sebuah kreativitas. Proses merupakan tahapan atau hal - hal yang dilakukan dalam mewujudkan sebuah karya. Sesuai dalam Kamus Besar Bahasa Indonesia bahwa proses merupakan rangkaian tindakan, pembuatan, atau pengelolahan yang menghasilkan produk (2001: 735). Proses kreativitas dalam menciptakan suatu karya tari dapat diawali dengan melihat. Melihat yang dimaksudkan bagaimana seorang koreografer dalam menafsirkan apa yang dilihat dengan panca indera untuk melatih pikiran yang lebih tajam mengenai apa yang dilihatnya, sehingga dapat memunculkan ide - ide yang baru dan kreatif seorang koreografer. Sehubungan dengan hal tersebut Soedarsono mengatakan bahwa pada dasarnya manusia mencari pengalaman kreatif dan pengalaman estetis, karena dari pengalaman yang ada pada dirinya. Proses melihat yang dikatakan sebelumnya dapat menjadi awal dari proses kreatif koreografer. Melalui pengalaman kreatif dan pengalaman estetis, koreografer dapat menjadi seorang yang berintegritas dan membantu koreografer merasa nyaman dengan dunianya ( 1978: 38). Prosesnya berkaitan dari karya tari yang sebelumnya dimungkinkan dan digunakan pada proses penciptaan Tari Harjuna - Keratarupo.

\section{PRODUK (PRODUCT)}

Definisi mengenai produk adalah hasil akhir dari proses kreatif. Sedangkan produk kreatif adalah hasil akhir dari kreativitasnya yang di dalamnya terdapat unsur orginalitas dan kebaruan dalam karya tari tersebut (Munandar,2002: 28). Berdasarkan 
pengertian Munadar, Tari Harjuna Keratarupo merupakan produk kreatif yang di dalamnya terdapat keoriginalitasan yaitu berupa ide penciptaan Tari Harjuna Keratarupo yang didasarkan pada penginterpretasian dari pencipta bahwa sebuah kebenaran akan selalu menang hal tersebut didasari dari cerita Arjuna Wiwaha. Tari Harjuna - Keratarupo salah satu tarian yang memiliki kebaruan pada vokabuler gerak tari phethilan. Kebaruan pada Tari Harjuna - Keratarupo merupakan keunikan dari Tari Harjuna - Keratarupo dengan penggunaan motif perangan yang diciptakan Dwiyasmono sendiri dan penggabungan gerak Gaya Surakarta dan Yogyakarta.

Produk kreatif Dwiyasmono dari Tari Harjuna - Keratarupo dapat dilihat dari motif beksan gendewa, perangan keris, perangan gendewo, perang panahan, kalang kinantang gaya Yogyakarta. Selain terdapat penggarapan pada motif gerak, ciri lainnya yang menandakan produk kreatif adalah busana yang dikenakan pada penari Tari Harjuna - Keratarupo. Hal ini tampak pada irah - irahan yang dikenakan penari pada tokoh Arjuna hanya menggunakan jamang dan uren sebagai penginterpretasian seorang Arjuna yang sedang berkelana dan bertapa dihutan.

Tari Harjuna- Keratarupo merupakan produk atau karya tari yang disusun berdasarkan pengalaman Dwiyasmono selama menjadi penari maupun koreografer. Pengalaman selama menjadi penari maupun koreografer selama bertahun tahun menjadikan Karya Tari Harjuna Keratarupo termasuk karya tari yang memiliki kualitas yang baik (Wahyu Santosa Prabowo, wawancara 27 September 2018).
Sehubung dengan hal tersebut Carl R.Rogers dalam kutipan Munandar menyatakan bahwa kriteria atau ukuran yang menjadi dasar penilaian untuk produk kreatif yaitu produk harus nyata dan merupakan hasil dari kualitas unik individu dalam interaksi dengan lingkungan (2002:28). Berdasarkan kriteria yang dinyatakan oleh Rogers, Tari Harjuna Keratarupo merupakan produk kreativitas Dwiyasmono dan memiliki kualitas unik individu berdasarkan interaksi dengan lingkungannya. Keunikan dari Tari Harjuna - Keratarupo yaitu penggunaan kendhang kosek pada musik tarinya, bahwasannya kendangan kosek biasa dipakai dalam pementasan wayang kulit. Sehingga penentuan proses kreatif menyangkut person atau pribadi, proses itu sendiri, dan produk kreatif. Proses kreatif sebagai kriteria kreativitas maka produk yang dihasilkan dari proses itu dianggap sebagai produk kreatif, dan orangnya dapat disebut orang kreatif.

Dwiyasmono dapat dikatakan sebagai orang yang kreatif dapat dilihat dari beberapa karya yang telah diciptakan. Produk kreativitas yang pernah diciptakan Dwiyasmono selain menciptakan karya Tari Harjuna - Keratarupo, Dwiyasmono juga menciptakan karya tari yang lain diantaranya Dramatari Karno Tandhing karya yang pertama kali Dwiyasmono ciptakan pada tahun 1986 sebagai karya tari yang diciptakan guna perwujudan Tugas Akhir S1 di STSI Surakarta. Selain itu karya tari pasihan Tari Regawa Prasetyasmara yang pernahia ciptakan dengan Hadawiyah Endah Utami diciptakan untuk mengisi acara pernikahan putri dari Anom Suroto. Penciptaan karya Tari Solah pada tahun 
2002, Karya Pertunjukan Titi'an yang diciptakan pada tahun 2003 sebagai penyelesaian studi S2 Jurusan Penciptaan Seni di ASKI Surakarta. Dwiyasmono juga mendapat giliran untuk menciptakan karya Tari Sesaji, menciptakan karya Tari Sesaji pada tahun 2012 untuk Dies Natalis ISI Surakarta, dan yang terbaru adalah Karya Tari Multimedia yang diciptakan sebagai karya tari penelitian pada tahun 2018. Karya Tari Harjuna - Keratarupo salah satu karya Dwiyasmono yang memiliki kualitas dan dapat dikatakan berhasil, yang diajdikan salah satu materi perkuliahan wajib semester $\mathrm{V}$ pada tari putra alus gaya Surakarta (Wahyu Santoso Prabowo, wawancara 27 September 2018). Jadi karya Tari Harjuna- Keratarupo merupakan proses kerja yang diawali dari menyusun konsep dan melalui tahapantahapan eksplorasi, improvisasi dan komposisi yang menjadi susunan produk tidak bisa dilepaskan dari person dan press.

\section{PENUTUP}

Tari yang diciptakan oleh Dwiyasmono pada tahun 1995 merupakan suatu bentuk karya tari gaya Surakarta yang berkarakter putra alus yang bertema peperangan yaitu Tari Harjuna Keratarupo. Penyusunan Tari Harjuna Keratarupo dalam rangka mempersiapkan pementasan karya dosen ISI Surakarta. Merupakan salah satu genre tari phethilan Tari Harjuna - Keratarupo mengambil ide dari cerita Arjuna Wiwaha tentang peperangan Harjuna melawan Keratarupo. Tari yang ditarikan oleh dua orang penari, dengan membawakan karakter yang berbeda yaitu berkarakter putra luruh dan putra lanyap.
Tarian ini sebagai salah satu materi perkuliahan semester $\mathrm{V}$ pada mata kuliah putra alus gaya Surakarta di Institut Seni Indonesia Surakarta. Hal tersebut bertujuan untuk menambah wawasan mahasiswa ISI Surakarta juga menambah materi perkuliahan yang bergenre tari pethilan. Tari Harjuna - Keratarupo memiliki struktur pertunjukan menjadi tiga bagian yaitu: maju beksan, beksan, dan mundur beksan. Secara bentuk Tari Harjuna - Keratarupo terdiri dari beberapa unsur yaitu: gerak, pola lantai, rias dan busana, properti, musik, waktu dan tempat pertunjukan.

Pada karya Tari Harjuna Keratarupo Dwiyasmono ingin memberikan warna yang baru pada genre tari phetilan gaya Surakarta dengan adanya vokabuler gerak baru yang ia ciptakan sesuai dengan wiled Dwiyasmono. Kreativitasnya juga terlihat pada temuan warna iringan musik tari bahwa ada kendangan kosek wayang kulit. Kreativitas Dwiyasmono dalam Tari Harjuna - Keratarupo banyak dipengaruhi oleh pengalamannya sebagai penari maupun koreografer. Kreativitas Dwiyasmono didukung oleh pribadi, pendorong, proses dan produk. Pribadi Dwiyasmono yang memiliki semangat dalam dunia seni menjadikan modal awal berkreativitas, sementara itu motivasi atau pendorong dari dalam dirinya mempengaruhi pembentukan gerak Tari Harjuna - Keratarupo yang ia ciptakan. Kreativitas Dwiyasmono terlihat dengan adanya vokabuler gerak baru pada bagian beksan, dengan penggabungan vokabuler gerak gaya Surakarta dan gerak gaya Yogyakarta merupakan proses kreatif yang ada pada diri Dwiyasmono dalam menciptakan Tari Harjuna - Keratarupo. 
Gerak gaya tari Yogyakarta sangat terlihat pada bagian tangan salah satu contohnya gerak kalang kinantang gaya Yogyakarta. Pada proses kreatif yang didukung oleh pribadi kreatif, serta faktor pendorong baik dari dalam maupun dari luar dirinya menjadikan Dwiyasmono sebagai koreografer yang memiliki kreativitas yang baik.

\section{DAFTAR PUSTAKA}

Aminudin. 2014. "Wireng Gatutkaca Dadung Awuk di Pura Mangunegaran". Skripsi S-1 Seni Tari ISI Surakarta: Surakarta.

Departemen Pendidikan Nasional. 2001. Kamus Besar Bahasa Indonesia. Jakarta: Gramedia Pustaka Utama.

Dewi, Ica Saputri. 2018. “ Kreativitas S.Maridi Dalam Tari Manipuren". Skripsi S-1 Seni Tari ISI Surakarta: Surakarta.

Dwiyasmono. 1995. "Catatan Proses Penciptaan Karya Tari Harjuna Keratarupo". Penciptaan Karya Dosen. ISI Surakarta.

Hadi, Sumandiyo. 2003. Aspek-Aspek Dasar Koreografi Kelompok. Yogyakarta: Lembaga Kajian Pendidikan dan Humaniora Indonesia.

Hapsari, Dwi Fani. 2014. “Kreativitas Boby Ari Setiawan dalam Karya Tari Hanacaraka." Skripsi S-1 Seni Tari ISI Surakarta: Surakarta.
Koentjaraningrat. 1982. Metode-Metode Penelitian Masyarakat. Jakara: Gramedia Pustaka Utama.

Langer, Suzanne K. 1988. Problematika Seni. Alih Bahasa FX. Widaryanto. Bandung : Akademi Seni Tari Indonesia .

Lestari Asih. 2013. “Kreativitas Elisa Vindu dan Dona Dhian dalam Karya Tari Topeng Panji Kayungyun." Skripsi S1 Seni Tari ISI Surakarta: Surakarta.

Martono, Hendro. 2008. Sekelumbit Ruang Pentas Modern dan Tradisi. Bandung: Cipta Media.

Moleong, Lexy J (Edisi Revisi). 2013. Metode Penelitian Kualitatif. Bandung: PT Remaja Rosdakarya.

Munandar, Utami, S.C. 2002. Kreativitas dan Keterbakatan. Jakarta: PT.Gramedia Pustaka Utama.

Munandar, Utami. 1999. Kreativitas dan Keberbakatan, Strategi Mewujudkan Potensi Kreatif dan Bakat. Jakarta: Gramedia Pustaka Utama.

Prihatini, Nanik Sri, dkk. 2007. Joged Tradisi Gaya Kasunanan Surakarta. Surakarta: ISI Press.

Putra, Puradhi Mahatva Yusanto. 2017. "Kreativitas Bambang Irawan Dalam Karya Tari Lawung Kasenopaten". Skripsi S-1 Seni Tari ISI Surakarta: Surakarta. 
Smith Jacqueline, Ben Suharto. 1985. Suparn, I. Umar . 1991. Arjuna Wiwaha. Komposisi Tari: Sebuah Pertunjukan Praktis Guru. Yogyakarta: Ikalasti.

Soedarsono. 1977. Pengantar Pengetahuan Tari. Jakarta : Lagaligo. Soedarsono. 1978. Pengantar Pengetahuan dan Komposisi Tari.Yogyakarta : ISI Yogyakarya.

Sulastuti, Katarina Indah. 2017. “Tari Bedhaya Ela - Ela Karya Agus Tasman Representasi Rasa Budaya Jawa" : Desertasi. Surakarta: UGM Yogyakarta.

Sumaryono. 2012. Ragam Seni Pertunjukan

Tradisional di Daerah Istimewa Yogyakarta. Yogyakarta: UPTD Taman Budaya.

Jakarta : Balai Pustaka.

Widyastutieningrum, Sri Rochana dan Dwi Wahyudiarto. 2014. Pengantar Koreografi. Surakarta: ISI Press.

\section{NARASUMBER}

Dwiyasmono. (56 tahun), dosen Jurusan Seni Tari, Institut Seni Indonesia (ISI) Surakarta. Karanganyar.

Wahyu Santosa Prabowo. (65 tahun), dosen Jurusan Seni Tari, Institut Seni Indonesia (ISI) Surakarta. Perumahan Pratama No.B9 Sabrang Kulon, Mojosongo, Jebres , Surakarta.

Takariyadi. (59 Tahun), Dosen Jurusan Seni Karawitan, Institut Seni Indonesia (ISI) Surakarta. Kemlayan Rt 02 Rw 02 Surakarta. 